\title{
PROFILE PEDAGOGICAL CONTENT KNOWLEDGE (PCK) OF PRIMARY SCHOOL TEACHER IN SCIENCE TEACHING
}

\author{
Margaretha Sri Yuliariatiningsih ${ }^{1}$, Lely Halimah ${ }^{2}$, Novi Yanthi ${ }^{3}$, Yona \\ Wahyuningsih ${ }^{4}$ \\ Universitas Pendidikan Indonesia Kampus Cibiru
}

\begin{abstract}
This research is to know pedagogical content knowledge (PCK) of primary school teachers is still far from standard with the average in science lesson. The main problem was that the results of UKG in 2015 illustrate the competence of elementary school teachers is still far from the standard with the average value reaches only 54.33 from the target of 55.00. The research method used survey method. Research subject is determined by purposive sampling technique. Research data were collected by interview technique, questionnaire, test, product assessment, and observation. Data were analyzed by one-way Anova toward civil servant period, certification period, work class, GPA and university origin. The conclusions obtained indicate that the teacher's PCK in teaching science in primary schools depends on the newly conducted training program such as the Teacher Education and Professional Training (PLPG). There is no correlation between the underlying factors as a teacher and the PCK in significantly teaching science in primary schools. It is recommended that teachers regularly attend training related to the updating of learning materials or related to PCK as the basis of the teaching profession in teaching science through an in-service training program.
\end{abstract}

Keyword: Primary school's teacher, science, pedagogical content knowledge.

\begin{abstract}
Abstrak: Penelitian ini untuk mengetahui pengetahuan konten pedagogis (PCK) guru sekolah dasar yang masih jauh dari standar rata-rata dalam pelajaran IPA. Masalah utamanya adalah bahwa hasil UKG pada tahun 2015 menggambarkan kompetensi guru sekolah dasar masih jauh dari standar dengan nilai rata-rata hanya mencapai 54,33 dari target 55,00. Metode penelitian menggunakan metode survei. Subjek penelitian ditentukan dengan teknik purposive sampling. Data penelitian dikumpulkan dengan teknik wawancara, kuesioner, tes, penilaian produk, dan observasi. Data dianalisis dengan Anova satu jalur terhadap data periodisasi pegawai negeri sipil, periodisasi sertifikasi, kelas kerja, IPK dan asal universitas. Kesimpulan yang diperoleh menunjukkan bahwa PCK guru dalam mengajar sains di sekolah dasar tergantung pada program pelatihan yang baru dilakukan seperti Pendidikan Guru dan Pelatihan Profesional (PLPG). Tidak ada korelasi antara faktor-faktor yang mendasari sebagai guru dan PCK dalam mengajar sains secara signifikan di sekolah dasar. Disarankan bahwa guru secara teratur menghadiri pelatihan terkait dengan pemutakhiran materi pembelajaran atau yang terkait dengan PCK sebagai dasar profesi guru dalam mengajar sains melalui program pelatihan dalam jabatan.
\end{abstract}

Kata Kunci: Guru sekolah dasar, sains, pengetahuan konten pedagogis (PCK).

\section{INTRODUCTION}

RPJPN Indonesia 2005-2025

focuses on the mission of human resource development to realize a nation that can be highly competitive. Development of qualified human resources throuh the education sector by increasing the qualification and certification of educators

\footnotetext{
'Universitas Pendidikan Indanesia Kampus Cibiru, Email: margarethasy国upi.edu

ZUniversitas Pendidikan Indonesia Kampus Cibiru

${ }^{3}$ Universitas Pendidikan Indanesia Kampus Cibiru, Email: navi.yanthi回upi.edu

${ }^{4}$ Universitas Pendidikan Indonesia Kampus Cibiru, Email: yonawahyuningsih回upi.edu
} 
(Bappenas, 2011). The program has the potential to provide incentives for teachers' professional allowance to teachers. Professional allowances have been enjoyed by $1,638,240$ teachers across Indonesia at all levels of education. Currently there are 555,467 teachers who have not yet had a certificate of educators and will follow the teacher certification program either through the PLPG which will be implemented until 2019 or PPG Teachers Certification Program (Kemendikbud, 2016).

There are several studies that show that certification has a positive effect on teacher performance but the results indicate that there is no significant correlation between professional allowances for certified teachers toward incentives for teacher competence development (Badrun, 2011; Edukasia, 2015; Sujianto, 2013; Kurniawan, Murniati, and Khoiri, 2011, Pink in Cristina, 2015) .

In relation to the above issues, since 2012, Kemendikbud has conducted teacher competency tests (UKG) to map the skills of teachers throughout Indonesia. The results of UKG in 2015 illustrate the competence of elementary school teachers is still far from the standard with the average value reaches only 54.33 from the target of 55.00 (Kemendikbud, 2016). Only nine regions with values above the national average, among them DI Yogyakarta $(66,36)$, Central Java, DKI Jakarta, West Java Provinces. The lowest value is in North Maluku Province (42.75). Overall, the competence of primary school teachers is below the national average (54.33 <56.69). In the pedagogic competency aspect, the national average of 45.54 ( $\mathrm{x}$ national $=48,94)$ is obtained; aspect of professional competence 53,06 (x national $=54,47)$; and aspects of professionalpedagogical competence 50.80 (x national $=53.02$ ).

The low self efficacy of teachers affects the improvement of professional competence of teachers (Tanriseven, 2012). In fact, with the increasing number of outstanding teachers, the more opportunities for other teachers to develop their competence through the collegial model of mentor.

It is undeniable that teacher training and education programs are important to ensure consistency of teacher professional development covering pedagogical, professional, pedagogical content knowledge (PCK) competencies (Pramana in Edukasia, 2015; Kurniawan, Murniati, and Khoiri, 2011; Febrianis, Muljono, Susanto, 2014).

In the practice of teaching in the classroom, the Regulation of the Ministry of Education and Culture of Indonesia no. 64 and no. 65 of 2013 on standard content and process standards, teachers must have pedagogical and professional competence in educating elementary students thematically-integrated. Basically elementary teachers (classroom teachers) should still have adequate pedagogicprofessional competence in teaching a variety of subject matter material subjects.

In addition, the student learning process should emphasize discovery / inquiry activities with project-based learning. In science, inquiry activities play an important role in the formation of cognitive schemes. Therefore, teachers are required to have special knowledge and skills to convey the subject matter of science (PCK).

Persico, Milligan, and Littlejohn (2015) explained that a lack of understanding of Science teaching strategies has an impact on learning ineffectiveness and low student learning outcomes. In addition, teachers who have low self-efficacy in teaching will tend to choose not to teach science (Riggs and Enochs, 1989) esecially when the topic of science shouold be taught by an integrated thematic method. As a result, students will learn less profound science.

Teachers play an important role in the process of forming qualified human resources. However, teachers often state that they have "taught" the maximum, but 
this does not have a positive effect on student learning outcomes.

One of the contributing factors is less effective learning strategy or approach. The method does not help students achieve indicators of competency achievement.

This is exacerbated by the lack of teacher mastery of teaching materials. That is, the pedagogical, professional, or integration competencies are both low to produce quality learning output.

This is relevant to the opinions of Axelrod, Aydin, Clark and Walsh that students believe in teachers' teaching experience, mastery of materials, ability to convey material, and appropriate teaching strategies affect the effectiveness of learning. Riggs and Enochs (1989) also stated that the self efficacy of teachers is very influential on student learning outcomes.

In science lesson, mastering the special skills and material in the science field owned by the teacher, does not guarantee able to teach the science material to the students and make the students' learning result increase (Hotaman in Febrianis, Muljono and Susanto, 2014).

Therefore, in relation to science learning in primary schools, teachers should use inquiry strategies as they are proven to improve students' motivation and learning outcomes. (Allen in Suduc, Bizoi, and Gorghiu, 2015; Hurd in Hacieminoglu, 2014).

Unfortunately, studies on the effectiveness of the pedagogical content knowledge or PCK methods of elementary school teachers are limited.

\section{METHODS}

Research methods is a mixed method of exploratory basic design followed by advanced -experimental design (Creswell, 2015) The object of research involves 28 elementary school teachers spread in West Java Province and DKI Jakarta Province. The respondent are teacher who has an above average UKG score, has served as a teacher for at least 8 years and has been certified professional educator and under 45 years of age.

Research instruments are teacher profiles and questions related to PCK teachers in teaching science in primary school. The research instrument was validated by curriculum experts, primary education specialists, science education specialists. The items of the instrument are questions about PCK in science teaching whose indicators cover the components of teacher competence according to Grossman. The question consisted of five open questions. Respondents' answers were collected as data on teacher's PCK in science teaching and other questions.

The collected data was analyzed using SPSS 18.0 program which is then described and statistically concluded. Testing correlation between influencing factors such as working period as civil servant, certification period, work class, IPK and university origin to teacher's PCK, conducted by using one -way Anova)

\section{RESULT AND DISCUSSION}

Table 1 show the statistical description of variable that affect pedagogical content knowledge ability, while Table 2 show the anova test result against variable affecting PCK ability.

Based on Table 2 it can be concluded that the average PCK teacher with a civil servant period of 15-19 years is greater than the average PCK teacher with a civil servant (PNS) under 15 years and even a teacher with the duty of being a civil servant (Civil servants over 19 years. From certification period variables, shows that the average ability of PCK teachers with the highest certification 0-1 years higher than teachers who have certification periods above 2-4 years. This case may occur because the new teacher is still fresh in getting professional training through the PLPG (Teacher Education and Professional Training). Based on the working class, grade III B teachers have an average PCK ability greater than III, A, III C, III D, even IV A teachers. 
Table 1. Statistical Description of Variables that Affect PCK Ability

\begin{tabular}{|c|c|c|}
\hline Category & $\mathbf{N}$ & Average PCK \\
\hline \multicolumn{3}{|c|}{$\begin{array}{l}\text { Year of } \\
\text { Service }\end{array}$} \\
\hline$<11$ years & 17 & 53,82 \\
\hline $11-14$ years & 5 & 53,60 \\
\hline $15-19$ years & 2 & 59,00 \\
\hline$>19$ years & 4 & 48,75 \\
\hline \multicolumn{3}{|c|}{ The Periode of Certification } \\
\hline $0-1$ years & 3 & 63,33 \\
\hline $2-4$ years & 14 & 51,71 \\
\hline$>=5$ years & 11 & 52,91 \\
\hline \multicolumn{3}{|c|}{ Class of Work } \\
\hline IIIA & 10 & 53,70 \\
\hline IIIB & 3 & 59,33 \\
\hline IIIC & 7 & 53,00 \\
\hline IIID & 4 & 48,25 \\
\hline IVA & 4 & 54,25 \\
\hline \multicolumn{3}{|c|}{ Cumulative Index } \\
\hline$>3,5$ & 7 & 52,71 \\
\hline $3-3,5$ & 12 & 55,75 \\
\hline$<3$ & 9 & 50,89 \\
\hline \multicolumn{3}{|c|}{ University Graduate } \\
\hline (PGSD) UPI & 8 & 57,50 \\
\hline $\begin{array}{l}\text { (PGSD) Non- } \\
\text { UPI }\end{array}$ & 9 & 49,44 \\
\hline $\begin{array}{c}\text { Language or } \\
\text { Math- } \\
\text { Science } \\
\end{array}$ & 9 & 53,22 \\
\hline $\begin{array}{c}\text { Non- } \\
\text { Language or } \\
\text { Math- } \\
\text { Science }\end{array}$ & 2 & 56,00 \\
\hline
\end{tabular}

Furthermore, the GPA obtained by teachers concludes that the average ability of PCK teachers who have a GPA of 3-3.5 is greater than teachers who have a GPA of <3> 3.5. In addition to the civil servant period, the certification period, the working class, and the GPA of teachers' PCK skills can also be seen from the university background. The average capacity of PCK teachers from the PGSD department of the University of Education of Indonesia (UPI) is highest among teachers from non-UPI PGSD. Thus, the civil servant period, the
Table 2. Anova test result against Variable Affecting PCK Ability

\begin{tabular}{|l|c|c|}
\hline \multicolumn{1}{|c|}{ Kategori } & Significance & Interpretasi \\
\hline $\begin{array}{l}\text { Periode PNS } \\
\text { government } \\
\text { employees) }\end{array}$ & 0,669 & $\begin{array}{c}\text { no significant } \\
\text { difference }\end{array}$ \\
\hline $\begin{array}{l}\text { Sertification } \\
\text { Periode }\end{array}$ & 0,159 & $\begin{array}{c}\text { no significant } \\
\text { difference }\end{array}$ \\
\hline Class of Work & 0,700 & $\begin{array}{c}\text { no significant } \\
\text { difference }\end{array}$ \\
\hline GPA & 0,519 & $\begin{array}{c}\text { no significant } \\
\text { difference }\end{array}$ \\
\hline $\begin{array}{l}\text { Univeristy } \\
\text { Background }\end{array}$ & 0,385 & $\begin{array}{c}\text { no significant } \\
\text { difference }\end{array}$ \\
\hline
\end{tabular}

certification period, the working class, the GPA and the university do not significantly affect the ability of the teacher's PCK. In other words it can be said that teachers tend to have the same or identical PCK.

Based on the findings of the research above, it appears that centralized education supervision and quality assurance policy and the determination of professional allowance allocation is less correlation with teacher performance in the classroom so that many teachers still feel in the comfort zone because they do not get any consequences from the low competence.

Febrianis, Muljono, and Susanto added that improving the ability of PCK teachers can be done through training programs.

This training program is regulated in Ministerial Regulation, Administrative Reform and Bureaucracy No. 16 of 2009. Teacher training programs should be tailored to the needs of aspects of teacher professional development (O'Sullivan in Febrianis, Muljono, and Susanto, 2014). Therefore, analysis activities need to be done before the training. If training is not based on the needs of teachers, it will not have a significant effect on the development of teacher competence, but it will potentially reduce learning motivation, in addition to consuming time, energy and cost. From some similar research results indicates that high school teachers' PCK still needs to be upgraded to fit the standards (Febrianis, Muljono, Susanto, 
2014). The findings of BSNP in 2009 based on the data of teacher ability test (UKG) revealed facts from 33 provinces that only $42 \%$ of teachers master pedagogical competence. This situation indicates the need for training programs to improve the methodological capabilities and teaching practices for teachers (Costica, 2015). Teachers should always develop their professionalism by always learning both formally and informally in their work environment (Jain and Martindale, Knowles in Salleh, 2015; Darling Hammond in Abidin, 2009).

\section{CONCLUSION}

Teacher's PCK in teaching science in primary school depends on the newlyconducted training program such as PLPG. There is no significant correlation between teacher background factors and PCK on how to teach science in elementary school.

\section{ACKNOWLEDGEMENTS}

Apreciation is addressed to the Ministry of Research and Technology Higher Education Indonesia through the first division of Research Higher Education (PUPT) in 2017 that has funded this research.

\section{REFERENCES}

Abidin, Y. (2009). Guru dan Pembelajaran Bermutu. Bandung: Penerbit Alfabeta.

Abidin, Y. (2009). Bermain. Bandung: Rizqi Press

Badrun, K. (2011). Kinerja Guru Profesional (Guru Pasca Sertifikasi). Cakrawala Pendidikan, November 2011, Th. XXX, No. 3

Bappenas. (2011). Rancang bangun Peningkatan Daya Sains SDM Indonesia. Info kajian Bappenas, vol 8, no. 2 .

Creswell, J. (2015).Riset Pendidikan Perencanaan, Pelaksanaan, dan Evaluasi Riset Kualitatif dan Kuantitatif Edisi kelima.
Diterjemahkan dari Educational Research, panning, Conducting, and Evaluating Quantitaive and Qualitative oleh Prajitno, H.S., \& Soetjipto, S.M. Yogyakarta: Pustaka Pelajar.

Costica, L. (2015). Elaborating A Pradigm for The Didactics of A Discipline. Dipresentasikan pada International Conference Education and Psychology Challenges-Teachers for The Knowledge Society- $3^{\text {rd }}$ Edition, EPC-TKS 2015. Procedia Social and Behavioural Sciences, 2013, 35-42.

Cristina, T. (2015). The Elephant in The Room or Updating The Teaching

Profession. Dipresentasikan pada International Conference Education and Psychology ChallengesTeachers for the Knowledge Society-3 ${ }^{\text {rd }}$ Edition EPC-TKS 2015. Procedia Social and Behavioural Sciences, 2013, 28-34.

Edukasia. (2015). Pasca Setifikasi Perlu Pelatihan. Suara Merdeka. Kamis, 26 Maret 2015.hal 9.

Febrianis, I., Muljono, P., Susanto, D. (2014). Pedagogical CompetenceBased Training Needs Analysis for Natural Science Teachers. Journal of Education and Learning. Vol.8 (2) pp.144-151.

Hacieminoglu, E. (2014). In-service Teachers' Perceptions Regarding their Practices Related to Integrating Nature of Science: Case Study. Procedia Social and Behavioural Sciences, 116,12681273.

Kurniawan, Murniati, Khoiri. (2011). Model Pengembangan Kompetensi Profesional Guru Fisika Kota Semarang Pasca Sertifikasi Melalui MGMP. JP2F, Volume 2 Nomor 2 September 2011.

Kemendikbud. (2016). Paparan Hasil UKG Tahun 2015. Kemendikbud. 
Persico, D., Milligan, C., Littlejohn, A. (2015). The Interplay Between SelfRegulated Professional Learning and Teachers' Work Practice. Procedia Social and Behavioural Sciences, 191, 2481-2486.

Riggs, I.M.; Enochs, L. G. Toward the Development of an Elementary Teacher'sScience Teaching Efficacy Belief Instrument. Paper presented at the Annual Meeting of the National Association for Research in Science Teaching (62nd, San Francisco, CA, March 30-April 1,1989).

Salleh, et.al, (2015). Competency of Adult Learners in Learning: Application of The Iceberg Competency Model. Dipresentasikan pada $4^{\text {th }}$ World Congress on Technical and Vocatinal Education and Training, 2014, Malaysia. Procedia Social and Behavioural Sciences, 2014,326-334.

Suduc, A.M., Bizoi, M., Gorghin, G.

(2015).Inquiry
Science Based
Primary Learning in
Dipresentasikan pada 6 $6^{\text {th }}$ Education.
Conference on
Counseling and Guidance, May
2015.

Sujianto. Pengembangan Profesionalitas Berkelanjutan/Continuing Professionality Development (CPD) Guru Bersertifikat Pendidik di SMK Rumpun Teknologi seMalang Raya. Jurnal Pendidikan Sains, Volume 1, Nomor 2, Juni 2013, Halaman 159-170

Tanriseven, I. (2012). Examining Primary School Teachers' and Teachers Candidates' Sense of Efficacy. Procedia Social and Behavioural Sciences, 47, 1479-1484. 